\title{
$\mathrm{HCV}$ 핵산증폭검사 양성 헌혈 혈액의 바이러스 유전자 정량 및 유전자형 분석
}

신선미 $\left.\right|^{1} \cdot$ 강재원 ${ }^{2} \cdot$ 강정원 $^{2} \cdot$ 서영익 $^{3} \cdot$ 박정란 $^{4} \cdot$ 이대동 $^{5} \cdot$ 민혁기 $^{6} \cdot$ 김명한 $^{3}$

대한적십자사 중앙혈액검사센터/품질관리팀 ${ }^{1}$, 대한적십자사 혈액수혈연구원/감염예방연구팀 ${ }^{2}$, 대한적십자사 중앙혈액검사센터 ${ }^{3}$, 대한적십자사 대전세종충남혈액원, 대한적십자사 남부혈액검사센터, 대한적십자사 중부혈액검사센터 ${ }^{6}$

\section{Analysis of HCV RNA Genotypes and Quantitative Values of Korean HCV NAT Reactive Blood Donors}

\author{
Sunmi Shin ${ }^{1}$, Jae-won Kang ${ }^{2}$, Jungwon Kang ${ }^{2}$, Young Ik Seo ${ }^{3}$, Jung Ran Park ${ }^{4}$, Dae Dong Lee ${ }^{5}$, \\ Hyukki Min ${ }^{6}$, Myunghan $\mathrm{Kim}^{3}$
}

Central Blood Laboratory Center, Korean Red Cross/Quality Management Team', Seoul, Blood Transfusion Research Institute, Korean Red Cross/TTI Research Team², Wonju, Central Blood Laboratory Center, Korean Red Cross ${ }^{3}$, Seoul, Daejeon Sejong Chungnam Blood Center Korean Red Cross ${ }^{4}$, Busan, Nambu Blood Laboratory Center, Korean Red Cross ${ }^{5}$, Jungbu Blood Laboratory Center, Korean Red Cross ${ }^{6}$, Daejeon, Korea

Background: Ever since the Korean Red Cross adopted HCV NAT for blood donor screening in 2005, HCV NAT reactive donors have been identified every year. The identification of the clinical features for these HCV NAT reactive donors may be helpful for the treatment and prevention of $\mathrm{HCV}$ infection.

Methods: We analyzed HCV NAT reactive samples to examine the distribution of HCV RNA genotypes and the quantitative values of 128 and $47 \mathrm{HCV}$ NAT reactive samples in 2007 and 2017, respectively.

Results: The dominant genotype of the HCV NAT reactive donors was 1 b showing $50.0 \%(64 / 128)$ in 2007 and $44.7 \%(21 / 47)$ in 2017. The genotype 2a was the second most dominant at 40.6\% (52/128) in 2007 and $40.4 \%$ $(19 / 47)$ in 2017. The mean titers of HCV RNA were $3.17 \times 106 \mathrm{IU} / \mathrm{mL}$ in 2007 and $2.61 \times 106 \mathrm{IU} / \mathrm{mL}$ in 2017. More than $90 \%$ of the donors showed a range of more than $1,000 \mathrm{IU} / \mathrm{mL}$ for the HCV RNA titer. There was no difference of quantitative values in the different genotypes.

Conclusion: In this study, the distribution of HCV RNA genotypes in Korean blood donors showed a similar pattern compared to that of the general population. There was no correlation between the quantitative values and genotypes in the HCV NAT reactive blood donors, and there was no significant variation in the distribution of HCV RNA genotypes of the HCV NAT reactive donors between 2007 and 2017. Yet it is thought that the characteristics of HCV NAT reactive samples in other years have to be analyzed to achieve more significant results. (Korean J Blood Transfus 2019;30:205-211)

Key words: HCV, Genotype, Quantitative values

Received on September 10, 2019. Revised on October 29, 2019. Accepted on November 15, 2019

Correspondence to: Jae-won Kang

Blood Transfusion Research Institute, Korean Red Cross/TTI Research Team, 50 Hyeoksin-ro, Wonju 26465, Korea

Tel: 82-33-811-0216, Fax: 82-33-811-0240, E-mail: kangjaewon@redcross.or.kr, ORCID: https://orcid.org/0000-0001-9030-4494

@ This is an Open Access article distributed under the terms of the Creative Commons Attribution Non-Commercial License (http://creativecommons.org/licenses/by-nc/4.0) which permits unrestricted non-commercial use, distribution, and reproduction in any medium, provided the original work is properly cited.

Copyright (C) 2019 The Korean Society of Blood Transfusion 


\section{서 론}

C형간염바이러스(hepatitis C virus, HCV)는 만 성간염, 간경변증 등의 간질환의 주요원인으로 [1], 우리나라 간경변증 및 간암환자의 약 $10 \sim 15 \%$ 가 $\mathrm{HCV}$ 에 기인하는 것으로 나타나 있다[2]. 과거 $\mathrm{HCV}$ 감염은 주로 수혈에 의한 경우가 많았으나, 1991년부터 국내 헌혈 혈액에 대한 HCV 항체검 사를 도입하였으며, 2005 년부터는 $\mathrm{HCV}$ 의 핵산 증폭검사(nucleic acid amplification test, NAT)를 실시하고 있어, 수혈에 의한 $\mathrm{HCV}$ 감염의 위험은 크게 감소하였다. HCV NAT는 도입 초기에는 Cobas AmpliScreen과 Procleix assay를 이용하여 mini pool 의 방법으로 검사를 실시하다가 2012년 2월부터 는 Procleix Ultrio Plus assay를 이용하여 개별검체 에 대한 검사를 실시하고 있다.

$\mathrm{HCV}$ 는 염기서열의 변이에 따라 일반적으로 6 개의 유전자형으로 구분되며, $\mathrm{HCV}$ 의 유전자형 은 항바이러스 치료의 약제나 치료기간을 결정하 는 주요 인자이다[3]. 전세계적으로 유전자형 1형 의 빈도가 $46 \%$ 로 가장 빈도가 높고, 3 형이 $22 \%$, 2 형 및 4형이 각각 $13 \%$ 를 차지하는 것으로 나타 나 있으며[4], 유전자형 3형은 동남아시아에, 4형 은 중동, 이집트, 중앙아프리카, 5 형은 남아프리 카, 6형은 홍콩, 마카오, 베트남에 주로 분포되어 있는 것으로 나타나 있다[5]. 국내의 경우 $1 \mathrm{~b}$ 형과 $2 \mathrm{a}$ 형이 가장 흔하고 기타 $1 \mathrm{a}$ 형, $2 \mathrm{~b}$ 형, 3형, 4형, 6 형 등은 $1 \%$ 미만으로 보고되어 있으며[6], 2005 년부터 2009년 동안 HCV NAT 양성으로 나타난 헌혈자에서의 유전자형 분포는 $1 \mathrm{~b}$ 형이 $47.7 \%, 2 \mathrm{a} /$ $2 \mathrm{c}$ 형 $35.5 \%$, 2형 7.6\%, 2b형 2.3\%, 1a형 1.3\%, 1형 $0.9 \%, 2 \mathrm{v}$ 형 $0.5 \%, 1 \mathrm{v}$ 형 $0.1 \%$ 로 나타나 있다[7].

본 연구는 2007년도와 2017년도 $\mathrm{HCV}$ 양성 헌 혈 혈액에 대한 유전자형 검사 및 $\mathrm{HCV}$ RNA 정 량 검사를 실시하여 국내 HCV NAT 양성 헌혈자
에서의 $\mathrm{HCV}$ 임상 자료의 변화를 관찰함으로써 향후 $\mathrm{HCV}$ 관련 헌혈 혈액의 안전 대책 강화를 위한 참고 자료로 제시하고자 하며, 더불어 검사 시약 및 장비 등의 임상 평가를 위한 재료로서 희 소성의 가치가 있는 귀중한 시료를 장기적으로 보관할 수 있는 체계를 마련하고자 하였다.

\section{대상 및 방법}

\section{1. 대상}

HCV NAT 양성 헌혈 혈액 163건(2007년)과 61 건(2017년) 중 시료가 확보되어 있는 128건(2007 년)과 47건(2017년)을 대상으로 하였다.

\section{2. 방법}

\section{1) HCV RNA 유전자형 분석}

HCV RNA의 core 단백 유전자와 5'-UTR 영역 을 표적으로 Sanger method에 의한 염기서열 분 석을 통하여 $\mathrm{HCV}$ RNA 유전자형을 분석하였다. MAgNa Pure 96 (Roche Diagnostics GmbH, Mannheim, Germany)을 이용하여 HCV NAT 양성 혈장 으로부터의 핵산을 추출하였으며, 역전사중합효 소연쇄반응으로 cDNA를 합성, 증폭 후 ExoSAPIT Express PCR Reagent (Thermo Scientific, MA, USA)로 증폭산물을 정제하였다. ABI 3730 DNA Analyzer (Applied Biosystems, CA, USA)를 사용하 여 염기서열을 분석 후 BLAST 검색을 통하여 유 전자형을 결정하였다.

\section{2) HCV RNA 정량검사}

Cobas TaqMan (Roche Diagnostics GmbH, Mannheim, Germany)을 이용하여 대상 검체에서의 $\mathrm{HCV}$ RNA에 대한 정량 검사를 실시하였다. 제조 사 $\mathrm{COA}$ (Certificate of analysis)에 따른 분석민감 도는 $98 \%$ 이며, 검출한계는 $10 \mathrm{IU} / \mathrm{mL}$ 이었다. 


\section{3. 통계 검증}

통계적인 유의성은 chi-square test를 이용하여 검증하였으며, 유의 수준은 $P<0.01$ 로 하였다.

\section{결 과}

\section{HCV RNA 유전자형 분포(Table 1)}

2007년도에 발생한 HCV NAT 양성 헌혈 혈액 128건과 2017년도에 발생한 HCV NAT 양성 헌혈 혈액 47 건 중 각각 64 건(50.0\%)과 21건(44.7\%)에 서 $\mathrm{HCV} \mathrm{RNA}$ 유전자형 $1 \mathrm{~b}$ 로 확인되어 가장 많은 분포를 보였으며, 그 다음으로 많은 분포를 보인 것은 $2 a$ 형으로 2007 년도의 경우는 52 건(40.6\%), 2017년도에는 19 건(40.4\%)이 확인되었다. $1 b$ 형과 $2 \mathrm{a}$ 형을 제외한 유전자형으로 확인된 사례는 2007 년도에 1a 1건, 2b 3건, 3a 1건과 2017년도에 2b 1건, 3a 1건이 있었다. 2007년 7건(5.5\%)과 2017년 5 건(10.6\%)의 경우는 유전자형을 확인할 수 없었 다. 2007년도와 2017년도의 유전자형 분포는 통 계적으로 유의한 차이를 보이지 않았다.

Table 1. Distribution of HCV genotype among the HCV NAT positive donors (2007 vs 2017)

\begin{tabular}{lcc}
\hline HCV genotype & 2007 & 2017 \\
\hline $1 \mathrm{~b}$ & $64(50.0 \%)$ & $21(44.7 \%)$ \\
$2 \mathrm{a}$ & $52(40.6 \%)$ & $19(40.4 \%)$ \\
$1 \mathrm{a}$ & $1(0.8 \%)$ & $0(0.0 \%)$ \\
$2 \mathrm{~b}$ & $3(2.3 \%)$ & $1(2.1 \%)$ \\
$3 \mathrm{a}$ & $1(0.8 \%)$ & $1(2.1 \%)$ \\
Undetermined & $7(5.5 \%)$ & $5(10.6 \%)$ \\
Total & 128 & 47 \\
\hline
\end{tabular}

\section{2, HCV RNA 정량검사 분포}

2007년도의 경우 128 건의 HCV NAT 양성 혈액 의 평균 $\mathrm{HCV}$ RNA의 역가는 $3.17 \times 10^{6} \mathrm{IU} / \mathrm{mL}$ (최 소 $4.51 \times 10^{1} \mathrm{IU} / \mathrm{mL}$, 최대 $5.01 \times 10^{9} \mathrm{IU} / \mathrm{mL}$ )로 나타 났으며, 2017년도의 경우 47건 중 1건은 정량값 을 도출하지 못하였고 나머지 46 건의 평균 $\mathrm{HCV}$ $\mathrm{RNA}$ 역가는 $2.61 \times 10^{6} \mathrm{IU} / \mathrm{mL}$ (최소 $1.51 \times 10^{1} \mathrm{IU} / \mathrm{mL}$, 최대 $2.21 \times 10^{7} \mathrm{IU} / \mathrm{mL}$ )로 나타났다. HCV RNA의 역가 범위별 분포를 살펴본 결과 Fig. 1과 같이 나타났으며, 2007년에는 128건 중 66건(51.6\%)이, 2017년에는 47건 중 22건(46.8\%)이 $10^{6} \sim 10^{7} \mathrm{IU} / \mathrm{mL}$ 범위의 HCV RNA역가를 보였고, $100 \mathrm{IU} / \mathrm{mL}$ 미만 으로 나타난 경우는 2007년 2건(1.6\%)과 2017년 3 건(6.4\%)이 있었다.

유전자형을 확인할 수 없었던 2007년도의 7건 과 2017년도의 5건의 HCV RNA 역가는 Table 2 와 같으며, 2017 년 1 건의 경우 선별검사에서의

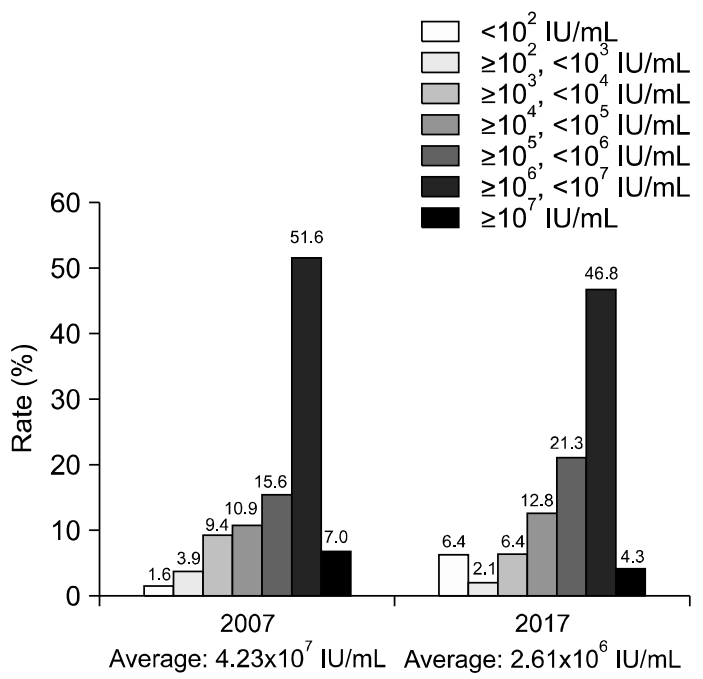

Fig. 1. Distribution of HCV RNA titer among the $\mathrm{HCV}$ NAT positive donors (2007 vs 2017). 
$\mathrm{HCV}$ NAT는 양성 결과를 보였으나, 정량값을 도 출하지 못한 경우이었다. 정량값을 도출한 혈액 중 $100 \mathrm{IU} / \mathrm{mL}$ 미만의 $\mathrm{HCV}$ RNA 역가를 보인 2007 년 2건과 2017년 2건은 모두 유전자형을 확인할 수 없었고, $100 \sim 1,000 \mathrm{IU} / \mathrm{mL}$ 의 역가를 보인 2007 년 5건 중 4건, 2017년 1건에서 유전자형을 확인 할 수 없었다. $1,000 \mathrm{IU} / \mathrm{mL}$ 이상의 역가를 보인 혈액 중 유전자형을 확인할 수 없었던 경우는

Table 2. HCV RNA titers in the donors whose genotypes have not been identified

\begin{tabular}{lcc} 
& Year of donation & $\begin{array}{c}\text { HCV RNA titer } \\
(\mathrm{IU} / \mathrm{mL})\end{array}$ \\
\hline Donor 1 & 2007 & $4.51 \times 10^{1}$ \\
Donor 2 & 2007 & $5.57 \times 10^{1}$ \\
Donor 3 & 2007 & $3.93 \times 10^{2}$ \\
Donor 4 & 2007 & $4.73 \times 10^{2}$ \\
Donor 5 & 2007 & $5.34 \times 10^{2}$ \\
Donor 6 & 2007 & $8.49 \times 10^{2}$ \\
Donor 7 & 2007 & $1.10 \times 10^{3}$ \\
Donor 8 & 2017 & $\mathrm{ND}$ \\
Donor 9 & 2017 & $1.51 \times 10^{1}$ \\
Donor 10 & 2017 & $1.53 \times 10^{1}$ \\
Donor 11 & 2017 & $6.77 \times 10^{2}$ \\
Donor 12 & 2017 & $2.93 \times 10^{3}$ \\
\hline
\end{tabular}

Abbreviation: ND, not detected in the quantitative assay.
2007년과 2017년에 각각 1건씩 나타났다(HCV RNA 역가는 각각 $1.10 \times 10^{3} \mathrm{IU} / \mathrm{mL}, 2.93 \times 10^{3} \mathrm{IU} / \mathrm{mL}$ ).

$\mathrm{HCV}$ RNA 유전자형별 $\mathrm{HCV}$ 역가는 Table 3 과 같으며, $1 b$ 형과 $2 a$ 형에서의 $\mathrm{HCV}$ RNA 역가의 차 이는 뚜렷하게 관찰되지 않았고, 그밖의 유전자 형인 $1 \mathrm{a}, 2 \mathrm{~b}, 3 \mathrm{a}$ 의 경우는 확인 건수가 적어 통계 적인 유의성을 관찰할 수가 없었다.

$\mathrm{HCV}$ NAT에서는 양성 결과를 보였으나, anti$\mathrm{HCV}$ 에서는 음성 결과를 보인 $\mathrm{HCV}$ NAT yield 사 례 중 2007년도 5건과 2017년 3건에 대한 유전자 형과 정량검사를 실시한 결과는 Table 4 와 같으

Table 4. HCV genotype and HCV RNA titer of the HCV NAT yield cases (2007 and 2017)

\begin{tabular}{lclc} 
& $\begin{array}{c}\text { Year of } \\
\text { donation }\end{array}$ & Genotype & $\begin{array}{c}\text { HCV RNA titer } \\
(\mathrm{IU} / \mathrm{mL})\end{array}$ \\
\hline Case 1 & 2007 & 1a & $2.95 \times 10^{5}$ \\
Case 2 & 2007 & Not clear & $1.10 \times 10^{3}$ \\
Case 3 & 2007 & 2a & $8.56 \times 10^{3}$ \\
Case 4 & 2007 & 2a & $1.07 \times 10^{3}$ \\
Case 5 & 2007 & 2a & $1.52 \times 10^{7}$ \\
Case 6 & 2017 & Not clear & ND \\
Case 7 & 2017 & Not clear & $6.77 \times 10^{2}$ \\
Case 8 & 2017 & Not clear & $1.51 \times 10^{1}$ \\
\hline
\end{tabular}

Abbreviation: ND, not detected in the quantitative assay.

Table 3. HCV RNA titers by the HCV RNA genotypes

\begin{tabular}{cccccc}
\hline HCV genotype & Year & Number & Mean & Min & Max \\
\hline $1 \mathrm{~b}$ & 2007 & 64 & $8.08 \times 10^{7}$ & $5.25 \times 10^{2}$ & $5.01 \times 10^{9}$ \\
& 2017 & 21 & $2.25 \times 10^{6}$ & $1.59 \times 10^{3}$ & $7.71 \times 10^{6}$ \\
$\mathrm{2a}$ & 2007 & 52 & $4.31 \times 10^{6}$ & $1.07 \times 10^{3}$ & $1.69 \times 10^{7}$ \\
& 2017 & 19 & $3.79 \times 10^{6}$ & $1.22 \times 10^{4}$ & $2.21 \times 10^{7}$ \\
$\mathrm{Ha}$ & 2007 & 1 & $2.95 \times 10^{5}$ & $2.95 \times 10^{5}$ & $2.95 \times 10^{5}$ \\
$\mathrm{ab}$ & 2007 & 3 & $3.52 \times 10^{6}$ & $3.46 \times 10^{4}$ & $6.04 \times 10^{6}$ \\
& 2017 & 1 & $6.66 \times 10^{5}$ & $6.66 \times 10^{5}$ & $6.66 \times 10^{5}$ \\
$3 \mathrm{a}$ & 2007 & 1 & $5.49 \times 10^{6}$ & $5.49 \times 10^{6}$ & $5.49 \times 10^{6}$ \\
& 2017 & 1 & $3.56 \times 10^{4}$ & $3.56 \times 10^{4}$ & $3.56 \times 10^{4}$ \\
\hline
\end{tabular}


며, 2017년의 HCV NAT yield 사례의 경우 모두 저역가 양상을 보여, 유전자형을 확인할 수 없었 다.

\section{고 찰}

$\mathrm{HCV}$ 양성 헌혈 혈액에 대한 역학적 특징의 규 명은 국내 $\mathrm{HCV}$ 감염 환자의 특징을 간접적으로 반영할 수 있을 것으로 보이며, 국내 $\mathrm{HCV}$ 감염 환자에 대한 치료 및 예방 방법 개선에 참고가 될 수 있을 것으로 판단되었다. 따라서 10 년 전후의 임상 자료의 변화를 관찰함으로써 국내 $\mathrm{HCV}$ 감 염자에 대한 변화의 추이를 간접적으로 파악하고 이를 통하여 국내에서의 $\mathrm{HCV}$ 감염자에 대한 관 리 및 치료 방법에 참고가 될 수 있을 것으로 판 단하였다. 또한 특이 유전자형을 지닌 감염 혈액 과 저역가 감염 혈액의 경우에는 향후 검사 시약 의 민감도 및 특이도 평가를 위한 재료로 사용될 수 있을 것으로 보였다. 따라서 국내 HCV NAT 양성 헌혈 혈액에 대한 바이러스 유전자 역가 및 유전자형을 분석함으로써 국내 $\mathrm{HCV}$ 감염 혈액 의 역학자료 도출과 더불어 향후 임상 평가에 적 합한 시료의 확보를 위한 참고 자료를 얻을 수 있 을 것으로 판단되었다.

대한적십자사 혈액사업 통계연보에 의하면 헌 혈혈액에서의 HCV NAT 양성 건수는 점차 감소 하여 2007년도에는 163건이었으나, 2017년도에 는 61 건으로 10 년 전에 비하여 약 $40 \%$ 로 감소하 였다[8]. 헌혈자에서의 HCV NAT 양성자 감소에 따른 HCV NAT 양성 혈액의 특징의 변화를 살펴 보고자, 2007년도와 2017년도의 HCV NAT 양성 헌혈 혈액 중 시료가 확보되어 있는 128건(2007 년)과 47건(2017년)에 대하여 HCV RNA 정량 및 유전자형 분포를 조사하였다. 연구 결과 2007년 도와 2017년도의 HCV NAT 양성 헌혈 혈액에서
의 $\mathrm{HCV}$ RNA 유전자형의 분포 및 정량값의 분포 에서 유의한 차이는 나타나지 않았지만, anti$\mathrm{HCV}$ 에서는 음성 결과를 보이면서 HCV RNA만 양성 결과를 보인 HCV NAT yield 사례의 경우는 2017년도에 발생된 사례의 경우 비교적 낮은 역 가를 보여, 대한적십자사에서 헌혈자에 대한 $\mathrm{HCV}$ NAT를 처음으로 도입한 2005 2006년도에 발생 된 HCV NAT yield 사례들에서 대부분 높은 역가 를 보인 것과[9] 다른 양상을 나타냈다.

유전자형이 확인된 HCV NAT 양성 혈액에서 의 유전자형 분포는 $1 b$ 와 $2 \mathrm{a}$ 가 대부분을 차지하 였으며, 그 밖에 $1 \mathrm{a}, 2 \mathrm{~b}, 3 \mathrm{a}$ 도 확인되었으나, 4 형 및 6형의 경우는 발견되지 않았다. HCV NAT 양 성 헌혈자에 대한 유전자형을 조사한 과거 연구 의 경우 당시 사용 시약에서는 $2 \mathrm{a}$ 형과 $2 \mathrm{c}$ 형을 구 분하지 못하여 $2 \mathrm{a} / 2 \mathrm{c}$ 형의 형태로 발표하였으나 [7,10], 본 연구에 사용된 방법에서는 $2 a$ 형만을 별 도로 도출할 수 있었다. 유전자형별 $\mathrm{HCV}$ RNA 역가의 경우에도 뚜렷한 차이를 보이지는 않았으 며, $1 \mathrm{~b}$ 형과 $2 \mathrm{a}$ 형을 제외한 기타 유전자형의 경우 는 발견된 건수가 적어 유효한 특성의 차이를 확 인할 수 없었다. $1 \mathrm{~b}$ 형과 $2 \mathrm{a}$ 형을 제외한 유전자형 의 경우 흔하게 발견되지 않기 때문에 향후 임상 연구의 소재로 활용하기 위해 장기 보관할 가치 가 있는 것으로 사료되었다.

$\mathrm{HCV} \mathrm{RNA}$ 정량검사 결과 절반 정도의 검체에 서 $10^{6} \sim 10^{7} \mathrm{IU} / \mathrm{mL}$ 의 역가를 지닌 것으로 나타났 고, $\mathrm{HCV}$ RNA 양성자의 평균역가는 2007년도 $\left(3.17 \times 10^{6} \mathrm{IU} / \mathrm{mL}\right)$ 와 2017 년도 $\left(2.61 \times 10^{6} \mathrm{IU} / \mathrm{mL}\right)$ 에 서 뚜렷한 차이가 없었다. $1,000 \mathrm{IU} / \mathrm{mL}$ 미만의 저 역가 양성자의 경우 2007년(5.5\%)에 비하여 2017 년도 $(8.5 \%)$ 에는 그 비율이 다소 증가하였다. 헌혈 혈액에 대한 NAT의 필요성이 처음 제기되었을 1990년대 후반에서 2000년대 초반 당시의 국제적 인 가이드라인에서는 $100 \mathrm{IU} / \mathrm{mL}$ 이상의 검출한 
계를 지녀야 하며, 혼합 검체(mini pool)를 이용할 경우 개별 검체에서 $5,000 \mathrm{IU} / \mathrm{mL}$ 이상의 역가를 지닌 $\mathrm{HCV}$ 감염 혈액을 검출할 수 있도록 요구하 였다[11]. 따라서 본 연구에서는 $5,000 \mathrm{IU} / \mathrm{mL}$ 미 만의 역가를 지닌 HCV NAT 양성 검체를 저역가 검체로 설정하여 저빈도 유전자형의 검체와 더불 어 장기 보관하면 좋을 것으로 여겨졌다.

본 연구에서는 10 년 전후의 $\mathrm{HCV}$ NAT 양성자 의 비교를 위하여 2007년도와 2017년도의 HCV NAT 양성 혈액에 대한 분석만 이루어졌지만, 보 다 유의한 결과의 도출을 위해 다른 연도에 발생 된 양성 혈액에 대한 분석도 필요할 것으로 판단 되었다. 본 연구과제 결과 대한적십자사 혈액수 혈연구원에서 보관 중인 $\mathrm{HCV} \mathrm{NAT} \mathrm{양성} \mathrm{혈액} \mathrm{중}$ 장기적으로 보관할 가치가 있는 혈액을 선별할 수 있었으며, 이들의 경우 향후 $\mathrm{HCV}$ 관련 임상 연구 및 검사 시약, 장비 등의 성능 평가를 위한 유용한 소재가 될 수 있을 것으로 사료되었다.

\section{요 약}

배경: 대한적십자사에서 2005년 헌혈자 선별검 사를 위한 HCV NAT를 도입한 이래, 매년 $\mathrm{HCV}$ NAT 양성 혈액이 확인되고 있다. 이들 $\mathrm{HCV}$ 양성 혈액에 대한 임상적 특징의 규명은 $\mathrm{HCV}$ 감염 예 방 및 치료에 도움이 될 것으로 여겨진다.

방법: 2007년과 2017년에 발생된 HCV NAT 양 성 혈액 중 시료가 확보된 128 건과 47건에 대하 여 유전자형 및 정량값의 분포를 분석하였다.

결과: $\mathrm{HCV}$ NAT 양성 헌혈자에서 가장 많은 분포를 보인 $\mathrm{HCV}$ 유전자형은 $1 \mathrm{~b}$ 로 2007년에는 $50.0 \%$ (64/128), 2017년에는 $44.7 \%$ (21/47)을 보였 다. 두번째로 많은 분포를 보인 유전자형은 $2 a$ 로 2007년에는 40.6\% (52/128), 2017년에는 40.4\% (19/47)을 보였다. HCV NAT 양성 헌혈자에서의
평균 $\mathrm{HCV} \mathrm{RNA} \mathrm{역가는} \mathrm{2007년에는} 3.17 \times 10^{6} \mathrm{IU} / \mathrm{mL}$, 2017 년에는 $2.61 \times 10^{6} \mathrm{IU} / \mathrm{mL}$ 로 나타났다. $90 \%$ 이 상의 헌혈자에서 $\mathrm{HCV} \mathrm{RNA}$ 역가가 $1,000 \mathrm{IU} / \mathrm{mL}$ 이상을 보였다. 서로 다른 유전자형에 대한 정량 값의 차이는 나타나지 않았다.

결론: 본 연구에서 국내 헌혈자에서의 $\mathrm{HCV}$ RNA 유전자형 분포는 일반 국민에서의 분포와 비교하여 비슷한 양상을 보였다. HCV NAT 양성 헌혈자에서의 정량값과 유전자형간의 상관 관계 는 나타나지 않았으며, 2007년과 2017년간의 HCV NAT 양성 헌혈자에서의 유전자형의 유의한 차 이도 나타나지 않았다. 그러나 보다 유의한 결과 를 얻기 위해서는 다른 연도에 발생된 HCV NAT 양성 헌혈자의 특징에 대한 분석도 이루어져야 할 것으로 사료되었다.

\section{References}

1. Hajarizadeh B, Grebely J, Dore GJ. Epidemiology and natural history of HCV infection. Nat Rev Gastroenterol Hepatol 2013;10:553-62

2. Lee SS, Byoun YS, Jeong SH, Kim YM, Gil H, Min BY, et al. Type and cause of liver disease in Korea: single-center experience, 2005-2010. Clin Mol Hepatol 2012;18:309-15

3. Jeong SH. Epidemiology of hepatitis $\mathrm{C}$ virus infection in Korea. Korean J Med 2015;88:630-4

4. Gower E, Estes C, Blach S, Razavi-Shearer K, Razavi H. Global epidemiology and genotype distribution of the hepatitis $\mathrm{C}$ virus infection. J Hepatol 2014;61(1 Suppl):S45-57

5. Messina JP, Humphreys I, Flaxman A, Brown A, Cooke GS, Pybus OG, et al. Global distribution and prevalence of hepatitis $\mathrm{C}$ virus genotypes. Hepatology 2015;61:77-87

6. Seong MH, Kil H, Kim JY, Lee SS, Jang ES, Kim JW, et al. Clinical and epidemiological charac- 
teristics of Korean patients with hepatitis $\mathrm{C}$ virus genotype 6. Clin Mol Hepatol 2013;19:45-50

7. Oh DJ, Park YM, Seo YI, Lee JS, Lee JY. Prevalence of hepatitis $\mathrm{C}$ virus infections and distribution of hepatitis $\mathrm{C}$ virus genotypes among Korean blood donors. Ann Lab Med 2012;32: 210-5

8. Korean Red Cross Blood Service Headquarters. Blood service statistic 2018. https://www.bloodinfo. net/promotion_yearstats.do [Online] (last visited on 3 September 2019)

9. Baclig MO, Chan VF, Ramos JD, Gopez-Cervantes J, Natividad FF. Correlation of the 5'untranslated region (5'UTR) and non-structural 5B (NS5B) nucleotide sequences in hepatitis $\mathrm{C}$ virus subtyping. Int J Mol Epidemiol Genet 2010;1:23644

10. Kang JW, Lee JS, Seo DH, Huh K, Wee JH, Park Q. Characteristics and follow-up results of the window period blood donors for hepatitis $\mathrm{C}$ virus. Korean J Blood Transfus 2007;18:15-22

11. Hennig H, Luhm J, Hartwig D, Klüter H, Kirchner H. A novel RT-PCR for reliable and rapid HCV RNA screening of blood donations. Transfusion 2001;41:1100-6 